\title{
Lobbying and Advocacy: Brussels' Competition Lawyers as Brokers in European Public Policies
}

\author{
LOLA AVRIL* \\ Université Paris I Panthéon-Sorbonne
}

\begin{abstract}
Studying the role of lawyers specialising in competition law, this paper shows that they are essential intermediaries between the European administrative field and the private sector. Using both qualitative (interviews and archives) and quantitative (database) methods, it demonstrates that intermediation activities developed in the late 1980s with the arrival of American law firms, which exported their working methods to Europe. This led to a fierce competition between law firms, which tried to recruit from inside the European Commission. Circulation between the European institutions started to be common and slowly became regulated, a process that gave it legitimacy. While new activities developed for a part of the legal profession, most notably lobbying and intermediation activities, lawyers contributed to blurring the border between the public and the private sphere at the European level. The importance of circulation between the administrative sphere and law firms and the embeddedness between the public and the private sector are thus incentives for overcoming institutional frontiers when studying the European field of power. Because circulation facilitates the development of social networks, common practices, and shared representations, it is essential to maintaining coherence within this 'weak field'.
\end{abstract}

Keywords: EU studies; sociology of professions, lobbying, revolving doors, political sociology of the EU, legal professions

Sociologický časopis/Czech Sociological Review, 2018, Vol. 54, No. 6: 859-879

https://doi.org/10.13060/00380288.2018.54.6.433

On 18 July 2018, the European Commission fined Google 4.34 billion Euros for breaching EU antitrust rules. According to the Commission, Google abused its dominant position by imposing restrictions on Android device manufacturers in order to promote its own services (for example, Google Search and Chrome). ${ }^{1}$ Right after the decision was issued, Google said it would appeal it before the European Court of Justice (ECJ). One might think that it is only when the case

\footnotetext{
* Direct all correspondence to: Lola Avril, Centre Européen de Sociologie et de Science Politique, Université Paris I Panthéon-Sorbonne, e-mail: lola.avril@univ-paris1.fr.

${ }^{1}$ European Commission, Press release, 'Antitrust: Commission Fines Google $€ 4.34$ Billion for Illegal Practices Regarding Android Mobile Devices to Strengthen Dominance of Google‘s Search Engine', Brussels, 18 July 2018.
}

(C) Sociologický ústav AV ČR, v.v.i., Praha 2018 
is brought before European judges that the company started to use the services of lawyers, but in fact, when the decision was made public, Google was already working with a few law firms in Brussels. ${ }^{2}$

In July 2018, the President of the European Parliament said that 'Google have contracts with the main law firms in order to prevent them defending other interests'. Indeed, the American company uses the services of Allen \& Overy (a member of the 'magic circle', i.e. the four biggest British law firms), Cleary Gottlieb (an American law firm ${ }^{3}$ ), White \& Case (an American law firm), and Slaughter \& May (a former member of the magic circle). ${ }^{4}$ These law firms are not located in Luxembourg, where the Court of Justice is, but in Brussels, near European administrative and political institutions. Hence, the judicial case, which began in July 2018, is just the tip of the iceberg, and the main work of lawyers specialising in competition policies is done well before.

This article tries to explore who are the lawyers who work for the private sector in Brussels, what they do, and how they have positioned themselves at the crossroads of the public and the private sector through the development of intermediation activities.

\section{Theoretical framework}

Law firms saw in European integration an opportunity for delivering new services. Some arrived in Brussels as early as 1957 (like Baker \& McKenzie). Others opened an office after the adoption in 1962 of a regulation regarding agreements and concerted practices. More came at the end of the 1980s with the adoption of the merger regulation. In Brussels, the proximity of law firms and European institutions is also geographic: law firms decided to set up offices near the European Parliament and the Commission, to 'access to strategic information' [van Criekingen and Decroly 2005].

While lawyers have been in Brussels since the beginning of European integration, they appear rarely in European studies. Alter [2001] or Trubek and Dezalay [1994] acknowledge that the development of European policies created incentives for lawyers and law firms to offer services related to them. Likewise, according to Slaughter, Stone Sweet and Weiler [1998: 239], 'lawyers specialising in EC law got more business through the growth and expansion of EC law'. In all these studies, lawyers seem to have a quite secondary and passive role in European integration. This article shows that lawyers also contributed to inventing their role at the European level. Specialising in European policies, they created a demand for their new services, and reinvented their role as intermediation

2 https://www.reuters.com/article/us-eu-google-lawyers-idUSKBN19V2EM.

${ }^{3}$ Elected American law firm of the year by the International financial law review in 2015.

${ }^{4}$ https://www.reuters.com/article/us-eu-google-lawyers-idUSKBN19V2EM. 
professionals in European policies. As in the Google case, they are now essential intermediaries between the European administrative field and the private sector.

Drawing on the approach of the political sociology of the European Union, this research focuses on the actors in EU polity, their trajectories and their sociological characteristics [Georgakakis 2013]. It aims to identify who is relevant in the making and implementation of European public policies, and to show that even if lawyers are not at the core of the 'Eurocracy', they managed to serve as brokers between companies and the administration. The issue of their work as intermediaries and their careers, at the crossroads of the public and the private sector, also raises a question relevant for the sociology of professions. Today, the tasks performed by lawyers and their sociological profile questions the specific nature of the legal profession compared to other consultants in EU public policies [Lahusen 2008; Büttner et al. 2015].

Since the mid-1980s, a new role for legal professions has thus been consolidated: a role involving intermediation activities between companies and the European administration. What is at stake here is a transformation of the legal profession, which is not just limited to European law or competition law, but involves the profession as a whole.

\section{A case study: competition policies}

Competition policies are historically a cornerstone of European integration. Competition policies, as the legal formulation of the economic ambition of the European project [Denord and Schwartz 2010], were partly created in Brussels. When the Treaty of Rome was signed, only France and Germany had legislation on this matter [Warlouzet 2010] and only the latter had created an independent institution in charge of the implementation of its policies [Patel and Schweitzer 2013]. Furthermore, the European Commission plays a great role in the elaboration and implementation of European competition policies. To apply rules regarding the abuse of dominant position, the prohibition of cartels, or the control of mergers, the Commission can investigate, hold hearings, grant exemptions, or impose fines.

During the 1980s, the DG for Competition benefitted from the popularity of a new economic school, namely neoliberalism [Cini and McGowan 1998] and the theories of the Chicago school, which make competition a central element in achieving economic growth. The formalisation and institutionalisation of the procedure surrounding competition cases made its decisions more legitimate and gave DG European officials the capacity to settle big cases, such as the IBM case in 1984. It also gave them a new impetus to draft legislation that went further towards a unified European economic regulation policy. Officials were more confident and the Commission was seen as 'no longer afraid, as it often seemed to be a few years ago, to hit big targets' (Financial Times, 5 September 1998). The 
three successive Commissioners in charge of competition in the 1980s were also more proactive in developing European competition policies: Frans Andriessen (1981-1985) considered competition policy a 'response to the industrial malaise' [Cini and McGowan 1998], embedded in the European industrial policy. Peter Sutherland (1985-1989) and Leon Brittan (1989-1993), both former barristers, continued his work.

While treaty provisions regarding state aids were barely implemented until the mid-1980s, the DG for Competition started in 1985 to systematically look at national subventions to easily identify illegal state aid [Cini and McGowan 1998]. The total amount of demands for recovery increased from ECU 11 million in 1986 to 747 million in 1988. At the end of the 1980s, following the will of Lean Brittan, the fight against state aid became a priority [Cini and McGowan 1998]. Regarding cartels and agreements, fines also increased, from ECU 12.7 million in 1985 to 60 million in 1986 (Financial Times, 5 September 1998). This increase was not only due to a rise in the number of cases resolved each year but also to a rise in the average amount of the fine imposed on companies (ECU 48 million for the case Soda Ash - 19 December 1990, ECU 75 million in the decision Tetra Pak of 24 July 1991).

As regards regulating mergers, the Commission started to work on a regulation at the beginning of the 1960s. Several draft regulations were debated during the 1970s but they were never adopted, because they were blocked in the Council [Ramirez Perez and van de Scheur 2013]. After the ECJ decision on Philip Morris in November 1987 (which allowed the Commission to forbid concentration on the basis of article 85 of the Treaty of Rome), a new draft regulation was published. The regulation, adopted in 1989, was an opportunity for law firms to sell new legal services: in March 1990, the Financial Times considered that 'every law firm in Brussels has spent the last three months picking through the regulation in response to inquiries from clients contemplating European takeover' (Financial Times, 26 March 1990). According to the journalist, 'cynics might say that the legal profession is over-estimating the complexity of the regulation with an eye to fees' (Financial Times, 26 March 1990).

Anti-dumping policies dealing with the massive arrival of cheap products in the European market were globally negotiated at the international level within the GATT. The first regulation was adopted in 1968 after the Kennedy round [Council 1968] but during the first decade, the regulation was barely implemented for several reasons [van Bael 1990]. The Tokyo round in 1979 led to the adoption of a new regulation [Council 1979], yet it was amended a few times (1984 and 1987) before being replaced by a new regulation in 1988, which finally brought all the provisions together in a single text. For law firms, these developments meant new business and new clients, who were previously not interested in European law. Companies from non-member countries such as Korea or Japan came to Brussels seeking legal advice. 


\section{Methodology}

These tremendous developments in European competition law made Brussels attractive for international law firms. This paper aims to understand the transformation of the role of European lawyers in this context since the end of the 1980s. How did they become essential intermediaries between the public and the private sectors? Why are they a good case for studying the blurriness of the borders between different fields ${ }^{5}$ at the European level?

This study is based on both quantitative and qualitative analysis. The first part is based on the systematic study of professional journals from the 1980s to the beginning of the 1990s, such as the International Business Lawyer or the International Financial Law Review. This last journal, where about 40 articles relating to the Brussels market for legal services were found (from 1980 to 1992), is a precious source because it echoes the internal debates of the legal profession. The International Lawyer, the journal of the American Bar Association (ABA Journal), and the journal of the antitrust section of the International Bar Association (International Business Lawyer) are dedicated to internal developments in European law and debates regarding the interpretation of European legislation. Articles from newspapers read in economic circles were also useful (Financial Times, Los Angeles Times, New York Times, Wall Street Journal).

Regarding the quantitative research, a database was created between 2013 and 2017. It consists of the trajectories of 455 competition lawyers based in Brussels from 18 different law firms. ${ }^{6}$ The database gathers information regarding the academic background of these lawyers (universities, diplomas), their professional career (positions held in the private sector or in public institutions, registrations to the bar), and other elements regarding their socialisation (affiliation to associations). Interviews with lawyers, civil servants, and lobbyists helped to interpret this quantitative data.

\footnotetext{
${ }^{5}$ The concept of 'field' as it is used here refers to Bourdieusian sociology. Fields are structured social areas organised around values, formal and informal rules and inside which there are competition and struggles [see Bourdieu 1980].

${ }_{6}$ The law firms were selected through the website Legal 500, which identifies the most important law firms for each legal specialty. All law firms appearing in the category 'competition law' in Brussels were included in the database. This includes British law firms (Allen \& Overy, Clifford Chance, Freshfields, Linklaters, Ashurst, Herbert Smith Freehills, Bird \& Bird) and American (Baker \& McKenzie, Cleary Gottlieb Steen \& Hamilton, Covington \& Burling, Hogan Lovells, Jones Day, Latham \& Watkins, Skadden, White \& Case, Arnold \& Porter, Gibson Dunn). There is also a 'niche' Belgian law firm, specialising in European law (Van Bael \& Bellis).
} 


\section{The invention of a new role for lawyers in the 1980s}

The rapid expansion of European competition law prompted a massive arrival of foreign law firms in Brussels. This phenomenon had two major consequences: first, operating in a competitive environment, law firms tried to offer new ranges of services, focusing on the intermediation, lobbying, and representation of their clients' interests before the European administrative and political institutions. Second, the invention of the intermediary role for lawyers in Brussels was also prompted by the arrival of Washington law firms, which triggered a professional debate about what were the good practices of a lawyer in Brussels.

\section{The development of intermediation activities in a competitive environment}

In the 1980s, Brussels began to be a place of opportunity for lawyers. Hence, there was a wave of openings of law firms in the European capital. While only five British law firms and six American law firms were established there in 1988, more than a hundred foreign law firms settled in Brussels between 1989 and 1993 [International Financial Law Review 1993]. Foreign law firms arrived in Brussels to offer new legal services. What is striking is that law firms preferred to expand to Brussels rather than Luxembourg, where the European Court of Justice is located. It indicates that lawyers dealing with European law interacted more with the political and administrative institutions (the European Parliament and the European Commission, located in Brussels) than with the judicial institutions (the European Court of Justice).

For Ivo van Bael, ${ }^{7}$ one of the first lawyers specialising in European law, 'it is very important, since EC law is based on a vague treaty with an activist court to know where you want to go, to look for the purpose behind the decisions and present your case along policy lines' [Stoakes 1984: 13]. Giving EC legal advice includes dealing with-or lobbying-the Commission on your client's behalf. As Louis van Lennep (former head of the Brussels' office of the Dutch law firm De Brauw en Helbach in the 1980s) states, 'competition law is a combination of law, economics and politics' [Stoakes 1984: 12]. Lobbying covers a variety of activities, from commenting on proposed legislation to negotiating with the Commission to obtain an exemption from the ambit of an existing regulation.

The rapid development in competition law prompted lawyers to be in regular contact with officials in the European Commission in order to 'know how to

\footnotetext{
${ }^{7}$ Ivo van Bael is a Belgian lawyer who graduated from the Michigan Law School in 1963. He then worked for the American law firm White \& Case (from 1963 to 1967 in New York and then from 1967 to 1969 in Brussels). In 1969 he joined the law firm of Jean-Pierre de Bandt, renowned for its transatlantic links and its working methods 'à l'américaine'. In 1986, he created with Jean-François Bellis his own firm specialising in European law.
} 
Table 1. Dates when foreign law firms arrived in Brussels (1979-1989, not exhaustive)

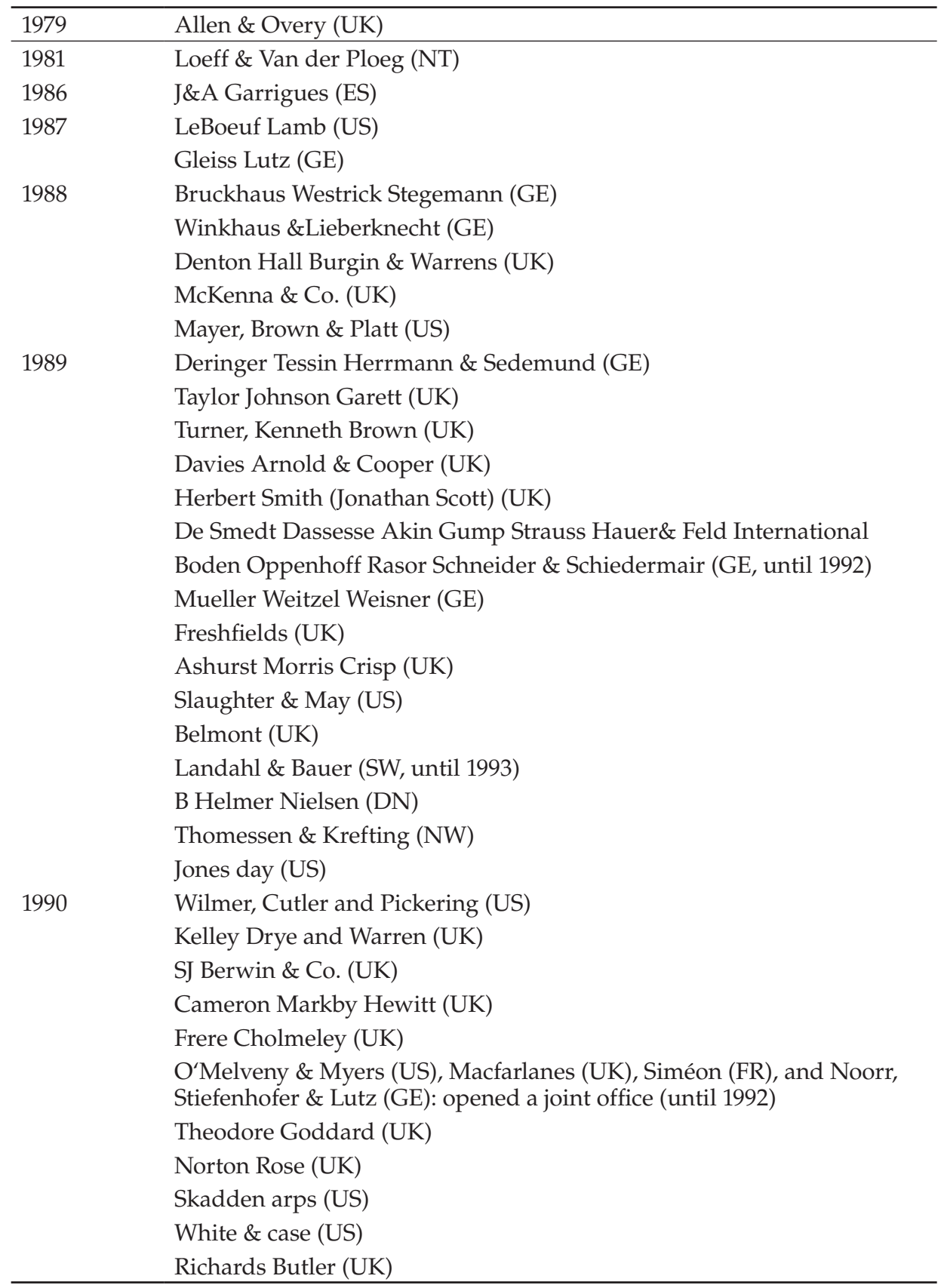


present a problem to the Commission' and to know 'its current attitudes' [Moore 1980: 16]. Intermediation activities became significant, as an integral part of the day-to-day working practices of lawyers based in Brussels. According to a lawyer at an English law firm interviewed in 1990 in the Financial Times, 'you could justify a Brussels presence for the sole purpose of lobbying and monitoring' (Financial Times, 19 October 1990). For lawyers, this new area of work involves following the negotiations of new regulations and directives and representing their clients' interests during their preparation. A lawyer explained that his law firm, which specialised in European law in the 1980s, 'act as a think tank, giving a legal overview, advising on strategy and the decision-making process in the Commission' [Stoakes 1984: 12].

These new activities were well received by officials in the Commission, who lacked legitimacy and means and were happy to have experts from outside of their services. A partner from Coudert Brothers said that the Commission asks for nothing more than not to draft in a vacuum, and to have input from as many sides as possible' [Stoakes 1984: 13]. Christofer Norall (from the niche law firm Forrester \& Norall) insisted that 'lobbying is a function of the institutions here: we're close to the nerve centre of the EC and new ground is being broken all the time. The person who wants something done or not done has real opportunities to make representations. The institutions can be very receptive' [Stoakes 1984: 13]. For another lawyer, 'many Commission officials have adopted an open-door policy, and are happy to sit down with you and discuss areas of concern' [Stoakes 1984: 13].

\section{Washington law firms' influence in question: towards 'lobbying à l'Européenne'}

The development of lobbying and intermediation activities in the legal profession was also prompted by the arrival of Washington law firms, which had been specialising for a few decades in lobbying political institutions.

Washington law firms started to show interest in Brussels' activities at the end of the 1980s. In 1989, Akin Gump, one of the leading law firms in Washington, signed a partnership with a Belgian law firm. The alliance was decided 'after realising that 1992 will demand radical restructuring in the international legal profession and that there are clear gains to be made by exploiting the Washington-Brussels nexus' [International Financial Law Review 1989a: 2]. The objective, put forward by the partner in charge of the alliance, was to 'bring US law firm methodology and technology into a European context', in other words, to export American practices in Brussels. The Washington law firm sent two American lawyers to the Belgian law firm to 'act as liaison with the Washington office' [International Financial Law Review 1989a: 2]. Another important Washington law firm, Wilmer Cutler \& Pickering, settled in Brussels in 1990. The law firm also planned 'to capitalize on the similarities between legal practice in Washington and Brussels' [International Financial Law Review 1989b: 8]. The New York law firm 
Winthrop Stimson also sent to Brussels the partner who already built up its lobbying practice in the Washington office 'to try the same formula in Brussels' [International Financial Law Review 1993: 10].

The massive arrival of American law firms in the Brussels' market of legal advice led to the creation of a distinctive practice of law. First, the arrival of American lawyers encouraged European law firms to develop a client-oriented and business-oriented practice. While the profession was built on the distance of commercial considerations (lawyers being at the service of the law and not their clients) [Karpik 1995], things began to change at the beginning of the 1990s. 'Working seven-day weeks to impress clients, the American firms are putting pressure on the reluctant Brussels bar to do likewise' [Greenhouse 1991: 1]. William Lee, a partner at Sherman \& Sterling, recalls: 'European lawyers ... go home for the weekend. You can call an American lawyer at three in the morning and ask a dumb question and he'll answer it. You wouldn't dare call a European lawyer at 3 am' [Pollock 1989: n.p.]. Progressively over the 1980s, the European lawyer changed 'his traditional role and offer[ed] a more business oriented service' [Brown 1984: 5].

Second, some of the practices adopted from Washington did not adapt well to the European context. Some attempts to transpose US techniques in Brussels led to failures and tensions within the legal community in Brussels and sometimes with European officials. They reveal the underlying principles of the interaction between European public administration and the private sector: while the Washington style relies on formal interactions with the administration and official public consultations, European lobbying is seen as more informal. European lawyers and officials thus complained about the huge amount of files and documents sent to them by American lawyers.

Newly arrived lawyers find practicing in Brussels quite different from operating in the United States, where proposed federal regulations must go through a formal process of public comment before they can take effect. The EC has no such formal procedure. [Havemann 1990: n.p.].

Sending too many documents and papers to officials could even be counter-productive:

The Americans are sometimes the target of ridicule, particularly for the reams of documents in which they have buried European Commission officials. [Greenhouse 1991: 1]

Professional conflicts about practices help us to identify what is specific in the intermediation role of lawyers in the European context: when one reads the professional newspapers of the early 1990s, it is possible to find numerous differences between the American way of lobbying and the European way. It appears from these articles that lawyers should avoid direct confrontation with officials and re- 
main polite in a small administration, where you will face the same person again and again on a specific subject. In 1991, a journalist from the New York Times, quoting an American lawyer on this question, wrote that 'here in Europe, it's impolite to be direct. If a client has deep concern with a proposal, you should say something like, "We support the desire of the Commission to do this, but we would invite the Commission to make the following small changes." In Washington you would say, "the agency's action was fundamentally wrongheaded, violates the statutory intent and is wrong for the following 17 reasons"' [Greenhouse 1991: 1]. A Swedish lawyer, working for a US law firm, also compared the 'EU style' and the 'Washington way' of lobbying: 'some US lawyers have earned a reputation in Brussels for hard lobbying, reminiscent of Washington, which in the past ... has aggravated the Commission and achieved the opposite result to that intended' [Stoakes 1984: 13].

Hence, in the late 1980s, with the development of European law and the arrival of foreign law firms in Brussels, a new way of practicing law was progressively established. In a competing environment, law firms started to offer new services, dedicated to the intermediation and the representation of their clients' interests before the European institutions. The adaptation of strategies imported by American law firms contributed to creating a new way of practicing law, which Daniel Kelemen called 'Eurolegalism' [2011]. It broke with two historical principles of the continental legal professions: a distance from the market and business activities and judicial and litigation-oriented day-to-day work. This new way of practicing law enabled the development of circulation between the legal profession on the one hand and the public or the private sector on the other hand.

\section{Circulation between the private and the public sectors}

Until the late 1980s, circulation between European institutions and the private sector was relatively rare. Some former civil servants chose to enter the academic sector or to seek an elected political position after their retirement, but the first departure for the private sector occurred in 1986. The development of a new way of practicing law in Brussels and the invention of a new role for lawyers specialising in European policies led to the development of circulation. This has had two consequences for the present day: first, former officials started to enter law firms and second, the professional border between lawyers and consultants in European affairs is now more blurred.

\section{Lawyers and officials from European institutions: the same sociological profiles}

The first case of a departure from the European Commission into the private sector appears to have been Aurelio Pappalardo [Seidel 2010]. Former director general for competition, after spending 26 years in the civil service, he opened his own law firm in 1986. Others followed, all of them at the age of retirement. The 
Table 2. International capital: countries visited during the studies (\%)

\begin{tabular}{lclc}
\hline Countries visited & Private & Public & Interns \\
\hline 1 & 19.2 & 25.5 & 10.1 \\
2 & 56.4 & 44.9 & 50.5 \\
3 or more & 16.7 & 27.5 & 35.8 \\
NR & 7.7 & 2 & 3.5 \\
\hline
\end{tabular}

Table 3. International capital: number of bar registrations (\%)

\begin{tabular}{lcc}
\hline Bar registration & Private & Public \\
\hline 0 & 0.8 & 10 \\
1 & 40.4 & 18.8 \\
2 & 37.3 & 48.8 \\
3 or more & 8.5 & 2.5 \\
NR & 13.1 & 20 \\
\hline
\end{tabular}

first departures from the Commission to law firms concerned primarily the for DG Competition. Today, this kind of circulation has become common and is not restricted to retired officials.

A database that contains the the profiles and professional trajectories (e.g. university education, diplomas, previous positions) of 455 European competition lawyers working in Brussels demonstrates the scale of this circulation. The population studied is composed of $40 \%$ women. This (relative) feminisation does not apply to all positions in the hierarchy, since $80 \%$ of associates are women and $90 \%$ of partners are men. The total population is internationalised : almost half of the population (49.3\%) is registered in two bars or more; $77.2 \%$ did their studies in more than one country (34.2\% in three countries or more); $33 \%$ have a diploma from the United States, $40 \%$ from a British university, and 22\% from the College of Europe (this illustrates the fact that the College of Europe did not succeed in supplanting Anglo-Saxon universities in training European lawyers). What is striking is the extent of circulation between European institutions and law firms in Brussels: only $57.1 \%$ of the studied population spent their whole career in the private practice (hereinafter 'Private'); $17.6 \%$ were officials (or contractors) in European institutions (hereinafter 'Public'); and $25.4 \%$ had only worked in European institutions on an internship (hereinafter 'Interns').

Therefore, we face a hybrid system where the border between public and private is blurred. As we will see in the following part, however, it is the acquisition of legal capital, of legal knowledge (and not of European resources or transnational resources), which makes circulation between institutions and law firms possible. 
A comparison of two groups, those who had previously worked in the public sector and those who spent their entire career in the private sector, shows the similarities in the sociological characteristics between regulators and those who are regulated at the European level. Both groups have the same features in terms of the resources related to acquiring international capital and European capital. ${ }^{8}$

As for international capital, comparing the two groups in terms of the number of countries visited during their studies or the number of bar registrations appears to be irrelevant, either because of a deficit of information or because the differences revealed in a comparison of percentages are too small.

As regards European capital, lawyers from European institutions and those from the private sector also have the same characteristics: more than a third of lawyers have a diploma in European law (37.5\% for the 'Public' profile and 38.08\% for the 'Private' profile), about one-fifth attended the College of Europe $(23.8 \%$ for the 'Public' profile and 21.5\% for the 'Private' profile).

Finally, with respect to academic capital, both groups, again, are similar: about $9.5 \%$ of the lawyers in both sub-populations have a doctorate, $85 \%$ have a master's degree. The only difference that can be noticed is that there are more lawyers in the private sector who have a diploma from an American university. But again, the statistical difference is not large enough to be relevant.

This comparison between the 'Public' profile and the 'Private' profile thus at first sight seems irrelevant, but it shows how competition lawyers are embedded in the administrative field at the European level. This goes hand in hand with another development: the blurriness between what law firms do and what consultancy firms do.

\section{New circulation between law firms and consultancies}

Since the beginning of 2000, intermediation activities have become increasingly autonomous and institutionalised. One of the lawyers interviewed recounts that over the past ten years he has dealt with cases where 'total cooperation between lobbyists, lawyers, economists ${ }^{\prime 9}$ was necessary. A partner from an American law firm established in Brussels estimates that 'half of his work time is not dedicated to purely legal activities: it involves talking with the public affairs department, going to see people'. ${ }^{10}$ These activities, which have increased significantly over the past years, also explain the emergence of revolving door circulation and a division of labour. This is in turn followed by structural changes within law firms.

\footnotetext{
8 The concept of capital derives from Bourdieu's work [1986] and refers to resources that are acquired in one field and are convertible into social position.

${ }^{9}$ Interview, partner, US law firm, Brussels, 17 February 2017.

${ }^{10}$ Interview, partner, US law firm, Brussels, 17 February 2017.
} 
From the end of the 1990s, some of the law firms started to open public affairs departments in their Brussels' office, which reflects the developments of lobbying activities: White \& Case in 1994, Freshfields in 1997, Allen \& Overy in 1999. People recruited into these departments had previously worked in European institutions. At Covington \& Burling Brussels in 2016, the team set up for 'regulatory and public policy' consisted of two former ambassadors, one political advisor to the French delegation of the EPP, one member of the Secretariat-General of the Commission, and one former delegate of European institutions to the United States. The public affairs department of White \& Case was launched by a former parliamentary assistant. Freshfields hired a former director-general of the Commission and a member of the DG for Justice.

Today, the mission of these departments is to treat all sorts of cases, giving advice on everything from the regulation of chemicals to the regulation of financial services. As public affairs departments developed, law firms started to recruit non-lawyers. This practice is a big departure from the core principles of the profession, especially in continental Europe, where the legal profession always set itself apart from other professions and from businesses. Public affairs departments now include people who previously worked in consultancy firms or lobbying firms. Out of the 6 members of the public affairs team at Covington \& Burling, only one has the title of lawyer and he previously worked at FIPRA, a consulting firm based in Brussels. The law firm also recruited Paul Adamson, nicknamed 'the godfather of lobbying' in Brussels, who created one of the first lobbying firms dedicated to European affairs in Brussels at the beginning of the 1980s. At Freshfields, the team is composed entirely of non-lawyers.

These recruitments show new types of circulation in the competition policy community: one between law firms and consulting firms, which are direct competitors in the area of European public affairs. Consulting firms entered the market of competition policies in the late 2000s. Some niche firms were created, like AVISA, and other more generalist firms set up departments dedicated to competition policies. These new consultancy firms recruited from the legal profession: at AVISA, a consultancy firm created by a former member of the cabinet of the Commissioner in charge of economic and financial affairs Yves-Thibault de Silguy, half of the department specialising in competition policies held a position in the biggest law firms (Gide Loyrette et Nouel, Simmons \& Simmons, Howrey, Cleary Gottlieb, Hogan Lovells, Freshfields, Ashurst). At FTI consulting, the competition team is directed by a former lawyer from Allen \& Overy and Herbert Smith. Sarah Biontino, a former lawyer in competition policies at Allen \& Overy created her own consultancy firm in 2005, after spending six years working for the European Commission. Elisabeth Crossick, a former lawyer in competition law, who launched a public affairs department in the law firm Freshields, was also recruited by APCO.

These new types of circulation between law firms and consultancy firms challenge one of the core principles of most legal professions in Europe (and 
especially on the continent): the distance it has historically retained from the market. They also question the basis of the definition of a profession, especially a regulated one, which is that it is relatively closed off from other professions and sectors.

\section{Evolving in a weak field: the constraints on circulation}

Vauchez [2008: 136] has shown that the European legal field is a weak one, with 'porous internal and external borders'. However, while the development of circulation has blurred the borders between the public and the private sectors, some elements demonstrate that the legal profession remains separated from the other sectors, retaining its own logics, stakes, and rules, despite the great permeability between fields.

The development of rules regarding conflict of interests and interactions between the public and private sectors

At the end of the 1980s, the first departures from European institutions into the private sector, and especially into law firms, generated a debate on potential conflicts of interests:

The European Commission was shaken and the director general at this time, knowing that I was familiar with the legal profession because I was a lawyer, talked to me and asked me 'we should set rules to forbid, at least for a certain period of time, conflict of interests'. ${ }^{11}$

While considerations of this began in the beginning of the 1990s, in the DG for Competition, it resulted in concrete outcome only in the 2000s, in the context of 'administrative modernisation' [Cini 2008], which sought to clarify the ethics rules that apply to the staff of European institutions after the Santer scandal. The DG for Competition was one of the first DGs to adopt such measures: in 2008, it had already adopted a code of conduct for its staff and a declaration for interns and had set up a task force on this issue as well as introducing an ethics compliance officer.

The Staff Regulation, adopted in 1968, was modified for the first time in 2004 and for the second time in 2013. This last reform tightens the rules regarding the departure of European civil servants in an amendment to Article 16: since 1962, officials had the duty to behave with integrity and discretion, but the regulation had left it to each institution to determine which activities should be subject to

${ }^{11}$ Interview, male, of Counsel, Brussels, 19 May 2014. 
the control exercised by the Appointing Authority for up to three years after a person's departure. This period was then reduced to two years. When the Appointing Authority thinks that the new activity a former official plans to engage in could lead to a conflict of interest, it can forbid him or her from taking the job or give its approval subject to conditions. Since 2013, officials cannot perform lobbying activities or represent interests on issues that they used to deal with in European institutions. Regarding other employees of European institutions, such as contractors, Article 16 also applies by analogy, but these rules remain vague and are rarely applied.

Circulation between public institutions and the private sector is thus relatively recent in the history of European institutions. 'Collusive transactions' [Dobry 2009], barely legitimate in the 1980s, have been codified and this codification has allowed their trivialisation and accompanied their development. The more lobbying activities were pursued by law firms, the more accurate their inclusion in the Transparency Register of European institutions became. Professional bodies regulating the legal profession, such as the bars, welcomed this new extension of the 'jurisdiction' [Abbott 1988] of lawyers. According to them, lobbying activities were consistent with the lawyer's mission, because enshrined in 'his action to defend the interests of his client, upstream of the traditional arenas for legal advice and litigation' [Kirch and Le Breton 2004: 2]. According to two competition lawyers in Brussels writing an article in 2004 in the Gazette du Palais, lobbying is 'an activity consistent with the lawyer's natural mission before the European institutions' [ibid.]. Because of the 'fluidity of the title' [Dezalay 1992], the legal profession can exercise 'intellectual poaching'. For the legal profession, lobbying is thus just another takeover in the market of services.

This takeover is validated by professional bodies: in 2011, the French-speaking Belgian bar authorised the exercise of activities of interest representation before European institutions. The Paris bar modified its internal rules in order to allow lawyers to comply with European rules in terms of transparency. The Brussels bar allowed lawyers to communicate the names of their clients and financial data related to activities such as lobbying if the client gave their consent.

However, despite these stances, the legal profession calls for exceptionality regarding the implementation of European transparency rules. From a rationalist point of view, this can be explained by its will to maintain a strategic advantage in the competitive market of Brussels public affairs. Hence, the 'legal profession recognises that it lobbies, explained the president of the French Conseil National des Barreaux, Paul-Albert Iweins, but it supports the principle that the lawyer exercises such activities in accordance with its deontology and he does not need any additional regulations' [Garnerie 2008: 1]. Even more, transparency rules would be in direct contradiction with some of the core principles of the profession, especially professional secrecy. Yet, those in the transparency register must declare the name of the businesses they represent and the budget they received from them to represent their interests. Hence, for a long time, law firms refused to be part of the Transparency Register. 
This register, created in 2008 by the European Commission and then extended to the European Parliament in 2011, is open to law firms. In 2012, a report from the European Parliament noted the reluctance of law firms to register. Dispositions regarding activities covered by the register are in favour of lawyers. Activities in the scope of the register are 'all activities carried out with the objective of directly or indirectly influencing the formulation or implementation of policy and the decision-making processes of the EU institutions' [European Parliament and European Commission 2011: n.p.], but Article 10, added after effective lobbying from the CCBE (Council of Bars and Law Societies of Europe), makes it possible to establish a distinction between legal advice and lobbying. ${ }^{12}$ But if the definition is clear from a legal perspective, it seems in fact much more blurred in practice. The text thus excludes from the scope of the register many activities that could be considered lobbying from another perspective, especially activities performed in the context of competition cases.

Today, 140 law firms are listed in the Transparency Register, of which 60 have an office in Brussels. The position of law firms regarding this register varies considerably: some fully play along (like Covington \& Burling, which declares the name of its clients but also the budget allocated to defend their interests, or Freshfields and DLA Piper). Others, like Linklaters, do not reveal their clients' names. Finally, some big law firms, despite their public claim to be engaged in public affairs (for example on their website) still do not want to register (White \& Case, Jones Day).

12 'Activities concerning the provision of legal and other professional advice are not covered by the register in so far as:

- they consist of advisory work and contacts with public bodies in order to better inform clients about a general legal situation or about their specific legal position, or to advise them whether a particular legal or administrative step is appropriate or admissible under the existing legal and regulatory environment;

- they consist of advice given to clients to help them ensure that their activities comply with the relevant law;

- they consist of analyses and studies prepared for clients on the potential impact of any legislative or regulatory changes with regard to their legal position or field of activity;

- they consist of representation in the context of a conciliation or mediation procedure aimed at preventing a dispute from being brought before a judicial or administrative body; or

- they relate to the exercise of the fundamental right of a client to a fair trial, including the right of defence in administrative proceedings, such as activities carried out by lawyers or by any other professionals involved therein.

If a company and its advisers are involved as a party in a specific legal or administrative case or procedure, any activity relating directly thereto which does not seek as such to change the existing legal framework is not covered by the register. This subparagraph applies to all business sectors in the European Union.' [European Parliament and European Commission 2011: n.p.] 


\section{The difficulty converting resources acquired in the public sector}

How does circulation between the public and the private sector happen in practice? First, this circulation is valued by the law firms, which specify, in the biographical information about their lawyers available on their website, the positions they have occupied in the public sector and the cases they dealt with during their time working for European institutions. Such profiles are highly valued. A lawyer met for an interview was offered a job by a law firm the first day he arrived in the Commission. Most of the lawyers interviewed actually did not have to look for a job in the private sector, they were directly contacted by the law firms.

However, not all jobs in European institutions are equal, and not all resources acquired in the administration are equally convertible for use in the private sector. Some resources are more valuable than others. Former positions in the DG for Competition are highly valued by law firms in Brussels, as it is the key interlocutor and the main opponent in competition policies. Altogether, $75 \%$ of lawyers in the database who had previously worked in the administration had held a position in the European Commission, and $62.5 \%$ of the latter had had position in the DG for Competition. Job experience in this DG is easily convertible in the private sector. It allows lawyers to become more familiar with its working methods and how the DG deals with cases, and it allows them to forge their own network of social relationships with the people they will face later when recruited by a law firm. The day-to-day work at the Commission is also an opportunity to meet all key actors in the competition policy network (law firms, lobbying firms, consultancy firms) and key actors in major companies. Hearings are opportunities to build this network: one lawyer recalls that he saw 'all the law firms that mattered ${ }^{\prime 13}$ there.

That is why working in the DG for Competition provides more resources that can be converted to use in the private sector than does a position in the legal service of the European Commission, where the work does not involve as many meetings with the private sector as in the DG for Competition and where day-today interactions are mostly with the Commission's other services or with the ECJ.

Finally, the database also shows that these types of circulation are not really career accelerators. When we compare competition lawyers who had been in the administration with competition lawyers who remained in the private sector, we find that having held a position in the administration does not increase your chances of being a partner in a law firm. Actually, it increases your chances of become a counsel, an off-counsel, or a consultant (see Table 4).

These are new positions that were created in Anglo-Saxon law firms about twenty years ago [Delaunay 2010]. They occupy an intermediate position between partner and association, leaving them with an uncertain status that does not require them to have shares in the law firm, and that is also an illustration of how the legal profession is changing. With this position, career development opportunities vary from law firm to law firm: in some firms, this position can be a

${ }^{13}$ Interview, lawyer, male, of Counsel, Brussels, 19 May 2014. 
Table 4. Hierarchical positions in law firms (\%)

\begin{tabular}{lccc}
\hline & Public & Private & Intern \\
\hline Associate & 32.5 & 55 & 84.4 \\
Counsel & 28.7 & 11.6 & 10.4 \\
Partner & 38.8 & 33.3 & 5.2 \\
\hline
\end{tabular}

temporary one that occurs before being named a partner. But in others, this position can be seen as permanent [Jensen 2010].

Sometimes, the conversion can also fail. The database is not useful for observing this phenomenon, but elements of these failures could be gathered in the interviews:

That said, you have people who left the Commission, but did not succeed as lawyers. Amongst the 4 people I mentioned, I would say that 2 succeeded but for some of them it was a catastrophe ... They could not adapt... it is a problem of mentality ... people who did not realise that ... when in the legal profession, you are responsible for a business, there is a commercial aspect, which is very important. And when you have done your full career as a civil servant, it is sometimes difficult to ... get rid of your civil servant suit ... and to wear the lawyer's one. ${ }^{14}$

Likewise, the fact that a former civil servant worked for an institution that is in fact its clients' opposing party in competition cases is sometimes not viewed well by businesses, which do not see the advantage of it:

I know that in some cases where a big company wanted to make use of my services ... inside this company there was a huge debate and some people said 'no, it is out of the question to work with ... after what he had done to us when he was at the Commission ... we will never work with the person' ${ }^{\prime 15}$

These difficulties encountered by some of the interviewees to convert their resources during the transition from the public to the private spheres are proof that despite the fact that the European field of power is a 'weak field' with blurred borders between the different social spaces, the sectors are still separate, and have their own logic and resources. However, it seems that, according to the qualitative and quantitative research, the opportunities for circulation are numerous and easy.

${ }^{14}$ Interview, male, partner, Brussels, 21 May 2014.

15 Interview, male, partner, Brussels, 21 May 2014. 
Intermediation activities began developing on a large scale at the end of the 1980s, with the arrival of American law firms, which tried to export their working methods relating to lobbying. This led to a fierce competition between law firms, which ultimately generated two consequences for the boundaries of the legal profession in Brussels.

First, law firms started to recruit officials from European institutions. Circulation between the public sector and the private sector is now common. This circulation, because it slowly became regulated, was made legitimate. Second, law firms developed new services, like lobbying, intermediation activities and the representation of their clients' interests before the political and administrative institutions of the EU. These activities were institutionalised inside law firms through the creation of dedicated departments and new types of circulation appeared, this time between law firms and consultancy firms.

In conclusion, the importance of such circulations, or 'collusive transactions', between the administrative sphere and law firms is an incentive to overcome institutional frontiers when doing research on the European field of power. This field of power is broader than that of the political and administrative bodies of the European Union alone. The need to include other actors and organisations in the analysis is reinforced by the fact that actors inside and outside institutions have the same sociological characteristics.

But these types of circulation, because they allow the development of social networks, common practices, and shared representations, are essential to maintaining coherence within this 'weak field' [Vauchez 2008]. For M. Dobry [2009], the collusive transactions help maintain the solidity and the stability of a complex political system like the European Union. Lawyers who master the knowledge shared by the different sectors that make up the European field of power are thus in good position to circulate and ensure the stability of this weak field.

Lola Avril is a PhD candidate at Université Paris I Panthéon-Sorbonne. Her research focuses on lawyers as intermediaries between the public and the private sector in European public policies. She is also co-director of the Research Group on the European Union of the French Association of Political Science, a member of the steering committee of the History of European Integration Research Society, and a member of the FOLIE (Forms of Life and Legal Integration in Europe) interdisciplinary group at Sciences Po Paris.

\section{References}

1989a. 'Brussels Breakthrough.' International Financial Law Review, May, p. 2. 1989b. 'Brussels Still Filling Up.' International Financial Law Review, August, p. 8. Abbott, A. 1988. The System of Profession. Chicago, IL: University of Chicago Press. Alter, K. 2001. Establishing the Supremacy of European Law: The Making of an International Rule of Law in Europe. New York: Oxford University Press. 
Bourdieu, P. 1980. 'Le Capital social.' Actes de la Recherche en Sciences Sociales 31 (1): 2-3.

Brown, C. 1984. 'Europe's Law Firms: The Next 10 Years.' International Financial Law Review: 5.

Bourdieu, P. 1987. ,The Force of Law: Toward a Sociology of the Juridical Field.' Hastings Law Journal 38 (5): 805-813.

Cini, M. 2008. 'European Commission Reform and the Origins of the European Transparency Initiative.' Journal of European Public Policy 15 (5): 743-760, https://doi.org/10.1080/13501760802133245.

Cini, M. and L. McGowan. 1998. Competition Policy in the European Union. Basingstoke: Macmillan, https://doi.org/10.1007/978-1-349-26710-1.

Council. 1968. Council Regulation 459/68 on Protection against Dumping or the Granting of Bounties or Subsidies by Countries Which Are Not Members of the European Economic Community, 5 April 1968, OJ L 93/1.

Council. 1979. Council Regulation 3017/79 on Protection against Dumped or Subsidised Imports from Countries Not Members of the European Economic Community, 20 December 1979, OJ L 339/1.

Council. 1984. Council Regulation 2176/84 on Protection against Dumped or Subsidized Imports from Countries Not Members of the European Economic Community, 23 July 1984, OJ L 201/1.

Council. 1987. Council Regulation 1761/87 amending Council Regulation 2176/84 on Protection against Dumped or Subsidized Imports from Countries Not Members of the European Economic Community, 22 June 1987, OJ L 167/09.

Council. 1988. Council Regulation 2423/88 on Protection against Dumped or Subsidized Imports from Countries Not Members of the EEC, 11 July 1988, OJ L 209/1.

Delaunay, O. 2010. 'Les Counsels à l'honneur au sein des cabinets d'avocats.' Option droit et affaires, 29 September.

Denord, F. and A. Schwartz. 2010. 'L'Economie (très) politique du traité de Rome.' Politix 89: 35-56, https://doi.org/10.3917/pox.089.0035.

Dezalay, Y. 1992. Marchands de Droit : la Restructuration de l'Ordre International par les Multinationales du Droit. Paris: Fayard.

Dobry, M. 2009. Sociologie des crises politiques. Paris: Presses de Sciences Po.

Garnerie, L. 2008. 'Lobbying: les avocats face à la réglementation européenne.' Patrimoine (July) 172: 1.

Georgakakis, D. 2013. Mapping the EU Staff and Professionals. Basingstoke: Palgrave.

Greenhouse, S. 1991. 'US Lawyers Flock to Brussels.' New York Times, 13 May, p. 00001.

Havemann, J. 1990. 'Doing Business: U.S. Law Firms Chasing New Clients in Brussels. They Hope to Cash in on the European Community's Quiet Revolution in the Way Businesses on the Continent do Business.' Los Angeles Times, 4 December.

Jensen, D. 2010. 'A quoi servent les statuts alternatifs à l'association?' La lettre des juristes d'affaires, 10 January: 1004-1005.

Karpik, L. 1995. Les Avocats, entre l'Etat, le Public et le Marché, XIIIe-XXe Siècles. Paris: Gallimard.

Kelemen, D. 2011. Eurolegalism. The Transformaton of Law and Regulation in the European Union. Cambridge: Harvard University Press, https://doi.org/10.4159/harvard.9780674061057.

Kirch, P. and G . Le Breton. 2004. 'L'avocat et le lobbying à Bruxelles.' Gazette du Palais (27 March) 87: 2.

Lahusen, C. 2008. ,Law and Lawyers in Brussels' World of Commercial Consultants.' EUI WORKING PAPERS RSCAS 2008/36. FI: European University Institute. 
Moore, A. 1980. 'The Brussels Connection.' Financial Times, 11 September: 16.

Pollock, E. 1989. ‘US Law Firms Catching 1992 Fever, Bet They'll Gain Edge in United Europe.' Wall Street Journal, 26 September.

Ramírez Pérez, S. and S. van de Scheur. 2013. 'The Evolution of the Law on Articles 85 and 86 EEC [Articles 101 and 102 TFEU]: Ordoliberalism and Its Keynesian Challenge.' Pp. 19-52 in The Historical Foundations of EU Competition Law, edited by K. Patel and H. Schweitzer. Oxford: Oxford University Press.

Seidel, K. 2010. The Process of Politics in Europe. The Rise of European Elites and Supranational Institutions. London: Tauris Publishers.

Slaughter, A.-M., A. Stone Sweet and J. H. H. Weiler. 1998. The Europe Court and National Courts-Doctrine and Jurisprudence. Legal Change in Its Social Context. Oxford: Hart Publishing.

Stoakes, C. 1984. 'Brussels' Supranational Law Firms.' International Financial Law Review, July: 9-17.

Trubek, D. and Y. Dezalay. 1994. 'Global Restructuring and the Law: Studies of the Internationalization of Legal Fields and the Creation of Transnational Arenas.' Case Western Reserve Law Review 44 (2): 407.

van Bael, I. 1990. 'EEC Antidumping Enforcement: an Overview of Current Problems.' European Journal of International Law 1 (1): 118-147, https://doi.org/10.1093/oxfordjournals.ejil.a035759.

van Criekingen, M. and J-M. Decroly. 2005. 'Local Geographies of Global Players: International Law Firms in Brussels.' Journal of Contemporary European Studies 13 (2): 173-187, https://doi.org/10.1080/14782800500212418.

Vauchez, A. 2008. 'The Force of a Weak Field : Law and Lawyers on the Government of the European Union (for a Renewed Research Agenda).' International Political Sociology 5: 128-144, https://doi.org/10.1111/j.1749-5687.2008.00040.x.

Warlouzet, L. 2010. The Rise of European Competition Policy: A Cross-Disciplinary Survey of a Contested Policy Sphere. Florence: RSCAS Working paper. 